\title{
分変マンション建替えの問題点と実現事例にみる対応策 COUNTERMEASURES FOR PROBLEMS IN CONDOMINIUM RECONSTRUCTION PROJECTS
}

\author{
長谷川 洋* \\ Hiroshi HASEGAWA
}

\begin{abstract}
This paper aims to clarify the countermeasures for problems in condominium reconstruction projects and to educe main factors to successfully carry reconstruction of condominium into execution, by adducing the existent reconstruction projects as examples.

Reconstruction of condominium has been mostly caried out by equivalent transfer method, using the differences between real floor area ratio and designed floor area ratio. Having good marketability to dispose reserved floor area by sale is needed to use this manner. It is also essential for those who have no means that developer providing small scale apartment units and purchasing condominium ownership to easily reach a mutual agreement among condominium owners. Appropriate supports by developer are needed for mortgagee, rental dweller and neighborhood. The small number of condominium owners to be reach a mutual agreement and strong leadership of reconstruction supporter are also essential, and cooperation among condominium owners in the stage of demolition and reconstruction works is really needed, because reconstruction project itself has no strong leagal supports.

Consequently, it is important to establish any methods where a mutual agreement is easily reached including those who has no means and the elderly, and they can join continuously to reconstruction projects. It is also important to give any legal basis in order to stabilize the process of condominium reconstruction works.
\end{abstract}

Keywords ; condominium, reconstruction, mutual agreement among owners, stability of project, countermeasures for problems 分僙マンション 建替え 合意形成 事業安定化 問題と対応策

\section{1. 研究の背景と目的}

1993年住宅統計調查によると、全国の持ち家・非木造・共同住宅 は188万9,600戸である。我が国においてこれらの分讓マンション(区 分所有の集合住宅）の供給が本格化したのは1960年代以降のことで あり、初期に建設されたものは既に築30年以上を経過し、建物の老 朽化や設備の旧式化、住戸規模の狭小化等が問題となってきている。 さらに、西暦2010年には（それまでの減失を考慮しなければ）39万 9,600 戸が公営住宅法における耐用年限の $1 / 2$ に相当する築後 35 年 を経過した中古ストックになると予想される。

これらの既存ストックについては、適切な維持管理を行い、でき る限り建物の長命化を図ることが重要である。しかし、そのうち老 朽化の著しい低質なストックについては、いずれ建替え需要が発生 することになり、また、不良ストックの発生による社会費用の増大 を防止する観点から建替えを推進する必要が生じてくるものと思わ れる。近い将来、老朽マンションの建替えが大きな社会的課題にな ることは疑う余地がない。

しかし、阪神・淡路大震災による被災マンション再建をめぐるト ラブルに象徴されるように"、分譲マンションの建替えにおいては、 戸建て住宅の建替えとは異なり、複数権利者間の合意形成を図る必 要があるが、それがなかなか円滑に進みにくい。また、区分所有法 や事業実施上にも多くの問題点が存在している。従って、これらの
諸問題点への対応策を的確に構勧していかない限り、今後のマンシ ヨン建替え需要に応えてゆくことは困難になると予想される。

以上の認識を背景として、本研究は、初動期の合意形成から事業 実施段階に至るまでの建替え事業の全進捗段階における問題点を整 理するとともに、既存の建替え実現事例においてその問題点が具体 的にどのように顕在し、それに対してどのような対応策を講じて事 業が実現したのかについて分析する。その結果、マンション建替え 実現の要因と課題を抽出し、今後のマンション建替え手法のあり方 を検討する基礎資料を得ることを目的とする。

ところで、マンションに係わる既往研究については、これまでの マンション問題の主流が維持管理であったため、管理組合の組織や 運営の実態及び所有者の管理意識等については膨大な研究蓄積が積 み重ねられてきた。一方、建替えを扱った既往研究は主として最近 10年以内になって報告されはじめ、その内容は大きくは、(1)同潤会 アパートの建替えに関するもの ${ }^{2} 、$ (2)初期の建替え事例の実態に関 するもの ${ }^{31} 、$ (3)建替えの実現可能性の予測に関するもの ${ }^{41} 、$ (4)管理 組合内部の合意形成プロセスに関するもの うち、本研究に直接的に関連する研究として上記(4)の視点からの文 献 8 があるが、そこでは建替えの是非から計画内容の提示・変更、 実施計画に至る間のプロセスにおいて、一般所有者、推進組織、外 部団体の行為と役割を通じて合意形成の過程のパターンを解明する $\begin{aligned} \text { * 建設省建築研究所住宅計画研究室 主任研究員 ·博士 (工学) } & \begin{array}{l}\text { Chief Researcher, Housing Planning Div., Building Research Institute, Ministry of } \\ \text { Construction, Dr. Eng. }\end{array}\end{aligned}$ 
ことに主眼が置かれている。このため、どのような合意形成を図る 上での問題点が具体的に存在し、それを解決するためにどのような 対応策が具体的に講じられているかについては直接の研究対象とは されておらず、本研究ではその点を扱う。また、本研究では区分所 有者の合意形成後の第三者の合意形成や、合意形成後の事業実施段 階での問題点とそれへの対応策についても扱っているが、この点に 関して具体的事例を通して整理した既往研究は存在しない6)。

\section{2. 既存の建督え雪例の特徵}

本節ではまず、既存の建替え事例の概要を擎理しておく。

阪神・淡路大震災による被災マンションの建替え事例? を除く と、一般の分譲マンション建替え実現例は現在までのところ全国で 45件程度であり、事業進行・計画中を含めても60件程度に過ぎない。

表一 1 は当初の分譲業者之建替え業者の関係を示している。当初 の分谼業者は日本住宅公団（現、住宅・都市整備公団）と住宅供給 公社が圧倒的に多く両者で 8 割以上を占める。一方、その後の建替 え業者は圧倒的に民間会社が多いのが特徵である。図ー 1 で建替え に伴う解体までの筑後年数をみると、30〜34年ついで35〜39年が多 い。既存の建替え事例の多くは日本住宅公団及び住宅供給公社が昭 和 30 年代に供給したものであると言える。

このような、初期の公的機関による物件の特徵は、指定容積率に 対して利用容積率に余裕のある点である。図ー 2 に示すように、従 前の容積率充足比（指定容積率に占める利用容積率の比）は、「0.2 〜0.3」「0.3〜0.4」が多く、容積率充足比の平均は 0.34 である。一 方、建替え後の容積率充足比は「1」近くに集中しており ${ }^{8)}$ 、余剩 容積率を使い切って指定容積率いっぱいに建替えられている状況が 分かる。大半が容積率 2 倍以上になっており、実に4 倍以上に増加 しているものもある。各戸の専有床面積を大きくする一方で、建替 え前後で住戸数を大幅に増加させ、保留床を生み出しているのであ る。建替え後の住戸数は従前に比べて全体平均で70戸増加している。

以上のように、余剩容積率を活用して保留床を生み出すことによ り、従前権利者の費用負担を（少）なくしている「等価交換」建替 えがこれまでの建替え事例の大半を占めているのである。

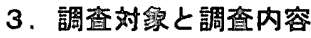

等価交換建替えにおいては、余剩容積率や立地条件、住戸数等の 諸条件により、等価交換後の無償還元床面積が異なる。また、少数

表 -1 従前の分淁業者と建替え業者

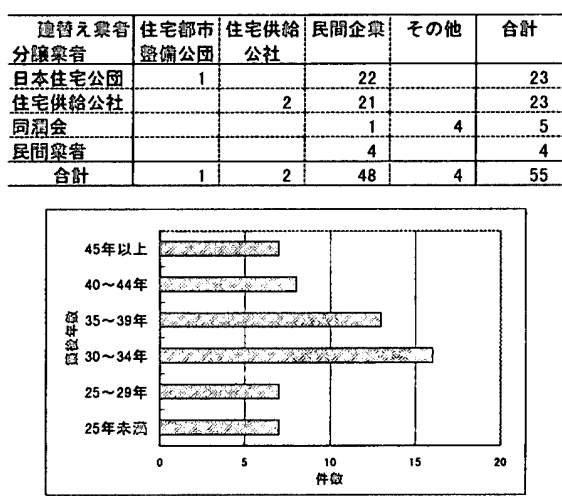

図一１＼cjkstart建替えに伴う解体までの築後年数
ではあるが等価交換型でない建替え事例や等価交換型でも全戸費用 負担が生じたケースもある。

本研究においては、既存の建替え実現事例の中から以下の表一 2 , 3 に示す 16 事例（事例 $\mathrm{A} \sim \mathrm{P}$ ）を調査対象とし、ディベロッパー に対するヒアリング調査を実施した。図一2において、本調查対象 事例を口印で示しているが、容積率充足比及び住戸数の建替え前後 の変化において、本調査対象事例は全建替え事例の中から様々な等 価交換条件・費用負担条件のケースを網羅している ${ }^{9 !}$ 。また、建替 えの合意形成が捗らず建替え計画検討が中断している 2 事例（事例 Q，R）についても、管理組合に対するヒアリング調查を実施した。

調查内容は、(1)建替え前後の建物の概要、(2)建替え検討段階での 居住者特性、(3)建替えまでの管理状況、(4)建替え発意に至る経緯、 (5)建替え事業の経緯、6)区分所有者間の合意形成上の問題とその対 応策、(7)第三者合意形成上の問題とその対応策、(8)事業実施上の問 題之その対応策、(9建替え成功の要因・中断の理由、等である。

調㚗結果をもとに、建替え前後の建物概要の変化を表 $-2^{101}$ 、 建替え検討時における居住者特性の概要を表一 3 に示している。

\section{4. 合意㷧娍段階での問題点と事例にみる封応}

建替えニーズが発意されると、外部専門家の協力を得て建替え推 進派の有志による勉強会 ${ }^{11}$ 、区分所有者全員に対する建替え意向 等に関する調查、ディベロッパーによる説明会等を経て、区分所有 者の合意形成を図ってゆくことになる ${ }^{12 !}$

\section{1 這智えの必要怪}

まず、建替えの必要性を説明しその是非を問うことになる。建替 えニーズ発生の最大の理由は建物の老朽化であるが ${ }^{13)}$ 、老朽化の 認識は個人の主観や世帯のライフステージ等に左右されるところが 大きい。事例Qはこの段階における建替えの是非をめぐる意見対立 が建替え検討中断の原因である。また、建物が老朽化していたとし ても建替えの必要があるのか大規模改修で対応できるのかの合理的 な判断が難しい。建替えよりも少ない費用での改修が可能な場合、 建替え推進は難しくなることがある ${ }^{14)}$ 。

実現事例においては、建替えか改修かをめぐる大きな対立は生じ ていない。その理由は、第一に、等価交換方式で原則として自己負 担なしに建替えができたケースが多いからである。改修するには自 己負担が必要であるが、建替えには必要がないというケースである。 しかし当然、自己負担が生じる場合には大規模改修や現状維持を主 張する者が現れ、建替え方針決定に手間がかかる（事例 A，K，N）。
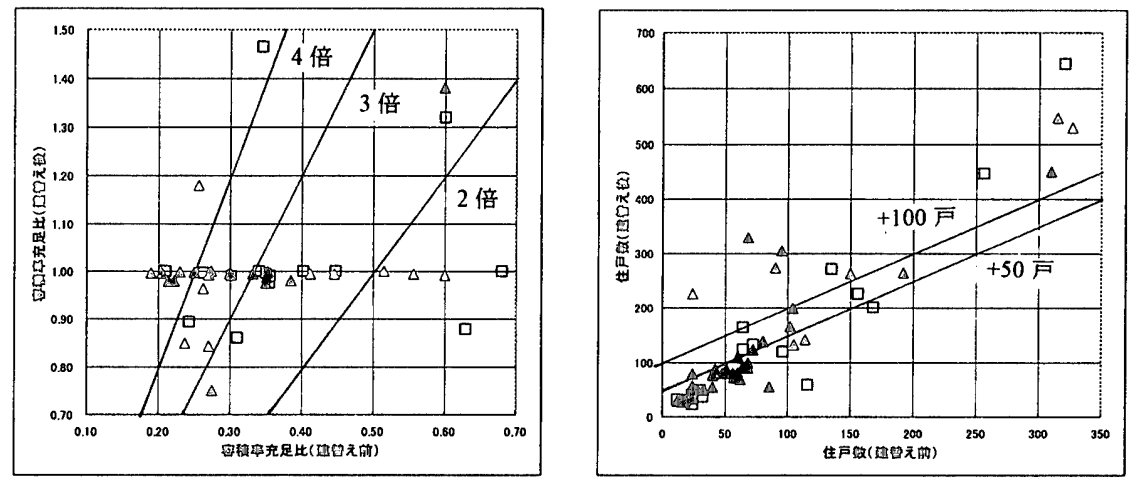

図一－建替え前後の容積率充足比と住戸数の変化 
表 -2 調査事例における建替え前後の建物概要の変化

\begin{tabular}{|c|c|c|c|c|c|c|c|c|c|c|c|c|c|c|c|c|c|}
\hline \multirow[t]{2}{*}{ 事例 } & \multirow[t]{2}{*}{ 建築年 } & \multirow[t]{2}{*}{ 事業方式 } & \multicolumn{2}{|c|}{ 棟数 (楮) } & \multicolumn{2}{|c|}{ 階数 (階) } & \multicolumn{2}{|c|}{ 利用容䅡率 (\%) } & \multicolumn{2}{|c|}{ 容種率充足比 } & \multicolumn{2}{|c|}{ 住戸数 (戸) } & \multicolumn{2}{|c|}{ 専有住戸面稹 $\left(\mathrm{m}^{2}\right)$} & \multirow{2}{*}{$\begin{array}{l}\text { 無償䤃元 } \\
\text { 面樌 }\left(\mathrm{m}^{2}\right)\end{array}$} & \multirow{2}{*}{$\begin{array}{c}\text { 最小賈用 } \\
\text { 負担額 (万円) }\end{array}$} & \multirow{2}{*}{$\begin{array}{l}\text { 単純売 } \\
\text { 却世带 }\end{array}$} \\
\hline & & & 前 & 後 & 前 & 後 & 前 & 後 & 前 & 後 & 前 & 後 & 前 & 後 & & & \\
\hline 事例A & S31 & 全部潩渡 & 1 & 1 & 4 & 5 & 101 & 140 & 0.51 & 0.70 & 24 & 23 & 48.5 & 76.7 & なL & 2.000 & 15 \\
\hline 事例 B & S32 & 土地信託 & 3 & 1 & 3 & 5 & 85 & 165 & 0.43 & 0.83 & 18 & 31 & 52.2 & $47.8 \sim 79.9$ & 52.8 & なし & 3 \\
\hline 事例C & S33 & 部分僙洨 & 1 & 1 & 4 & 7 & 72 & 199 & 0.36 & 0.99 & 24 & 41 & 44.7 & $64.8 \sim 106.0$ & あり & $200 \sim 2,760$ & 5 \\
\hline 事例D & $\mathbf{S 4 5}$ & 全部融渡 & 3 & 1 & 4 & 11 & 59 & 200 & 0.30 & 0.99 & 64 & 124 & 48.4 & $52.9 \sim 91.7$ & 52.9 & なL & 3 \\
\hline 事例 $\mathrm{E}$ & S34 & 部分譲渡 & 2 & 1 & 4 & 4 & 78 & 148 & 0.52 & 0.99 & 32 & 36 & 49.8 & $69.3 \sim 79.2$ & 69.3 & なし & 1 \\
\hline 事例 F & 533 & 部分讓渡 & 1 & 1 & 5 & 9 & 77 & 354 & 0.26 & 1.18 & 30 & 49 & 59.2 & $98.6 \sim 123.4$ & 98.6 & なL & 0 \\
\hline 事例G & $\$ 32$ & 部分譲渡 & 6 & 1 & 4,5 & 14 & 69 & 293 & 0.35 & 1.47 & 135 & 271 & $37.3 \sim 41.5$ & $56.2 \sim 88.4$ & 63.0 & なL & 0 \\
\hline 事例 $\mathrm{H}$ & S32 & 部分謫渡 & 12 & 3 & 4 & 14.15 & 69 & 205 & 0.34 & 0.99 & 256 & 447 & $41.9 \sim 58.3$ & $66.8 \sim 125.5$ & 71.9 & なし & 12 \\
\hline 事例 I & 532 & 全部融渡 & 18 & 1 & 2 & 8 & 42 & 199 & 0.21 & 0.99 & 116 & 59 & $37.6 \sim 39.2$ & $66.1 \sim 70.3$ & なL & 1.500 & 113 \\
\hline 事例K & $\mathrm{S} 32$ & 全部镶渡 & 7 & 3 & 4 & 9,10 & 91 & 199 & 0.60 & 1.32 & 168 & 201 & $45.0 \sim 55.0$ & $53.9 \sim 120.0$ & 30.0 & $700 \sim 1,700$ & 29 \\
\hline 事例 L & s30 & 全部嬢渡 & 7 & 3 & 3,4 & 5,12 & 62 & 172 & 0.31 & 0.86 & 296 & 359 & 32.5 & $40.0 \sim 91.0$ & あり & $100 \sim 1,400$ & 40 \\
\hline 事例M & $\mathrm{S} 32$ & 全部墪渡 & 1 & 1 & 3 & 6 & 53 & 199 & 0.27 & 0.99 & 12 & 32 & 50.8 & $63.1 \sim 89.2$ & 63.1 & なし & 2 \\
\hline 事例 $N$ & $\$ 32$ & 全部壤渡 & 4 & 2 & 3 & 6 & 126 & 199 & 0.63 & 0.99 & 72 & 132 & $50.2 \sim 52.4$ & $56.2 \sim 97.6$ & あり & $400 \sim 1,600$ & 6 \\
\hline 事例O & S33 & 部分譲渡 & 8 & 1 & 3.4 & 15 & 60 & 199 & 0.30 & 0.99 & 156 & 226 & 42.1 & $63.3 \sim 130.1$ & 82.0 & なし & 3 \\
\hline 事例 P & 542 & 全部孃渡 & 2 & 1 & 4 & 10 & 81 & 199 & 0.41 & 0.99 & 64 & 123 & 50.3 & $57.5 \sim 108.6$ & 70.0 & なL & 6 \\
\hline 事例Q & & & 39 & & 5 & & 69 & 250 & 0.35 & 1.23 & 998 & 1,296 & 46.8 & & 42.0 & & \\
\hline 事例 R & & & 19 & 7 & 5 & 14,27 & 56 & 235 & 0.32 & 1.18 & 780 & 1,723 & $48.0 \sim 53.0$ & & 70.0 & & \\
\hline
\end{tabular}

注I）事例 $Q ， R$ は建替え㛟捨中断事例。表中り数值は企画段階のもの

注2）事例 $\mathrm{G}, \mathrm{H}, \mathrm{K} \sigma$ 無供邀元面掼は最小值

表一 3 調査事例における建替え検討時の居住者特性

\begin{tabular}{|c|c|c|c|c|c|c|}
\hline \multirow[t]{2}{*}{ 事例 } & \multicolumn{2}{|c|}{ 個人所有戸数 } & \multirow{2}{*}{$\begin{array}{l}\text { 法人所 } \\
\text { 有戸数 }\end{array}$} & \multirow{2}{*}{$\begin{array}{l}\text { 所有者 } \\
\text { 無空家 }\end{array}$} & \multicolumn{2}{|c|}{ 中心的世帯特性 } \\
\hline & 自居住 & 賃貸 & & & 世带主年齢 & 世带型 \\
\hline 事例 A & 22 & 2 & 0 & 0 & 50歳代 & 夫婦のみ \\
\hline 事例B & 18 & 0 & 0 & 0 & $50 \sim 60$ 歳代 & 夫婦，単身 \\
\hline 事例C & 6 & 0 & $18(3)$ & 0 & 40～50歳代 & 核家族 \\
\hline 事例D & 56 & 6 & $2(1)$ & 0 & 50〜60歳代 & 核家族，夫婦 \\
\hline 事例 E & 19 & 6 & $7(5)$ & 0 & 40～50歳代 & 核家族 \\
\hline 事例 F & 25 & 0 & $5(1)$ & 0 & $60 \sim 70$ 歳代 & 夫婦，単身 \\
\hline 事例G & 10 & 22 & $103(19)$ & 0 & $50 \sim 60$ 歳代 & 核家族，夫婦 \\
\hline 事例H & 63 & 21 & $172(24)$ & 0 & $50 \sim 70$ 歳代 & 夫㛿，单身 \\
\hline 事例 I & 0 & 116 & 0 & 0 & & \\
\hline 事例 J & 42 & 50 & $228(15)$ & 0 & 60歳代 & 夫婦，単身 \\
\hline 事例K & 37 & 12 & $119(10)$ & 0 & $40,50,70$ 歳代 & 核家族，夫㛿，単身 \\
\hline 事例 L & 6 & 10 & $130(4)$ & 150 & 60歲以上 & 夫夢，単身 \\
\hline 事例M & 6 & 5 & $1(1)$ & 0 & $40 \sim 60$ 歳代 & 核家族，夫婦 \\
\hline 事例N & 23 & 10 & $39(6)$ & 0 & 50〜60歳代 & 核家族，夫婦 \\
\hline 事例O & 68 & 12 & $76(17)$ & 0 & 40〜60歲代 & 核家族，夫婦 \\
\hline 事例P & 59 & 5 & 0 & 0 & 50〜60歳代 & 核家族，夫婦 \\
\hline 事例Q & 776 & 155 & 10 & 27 & 40～50歳代 & 核家族 \\
\hline 事例 R & 603 & 127 & 8 & 42 & 50〜60歳代 & 核家族，夫绶 \\
\hline
\end{tabular}

第二は、建物の物理的老朽化以外の建替え発意が埋め込み配管の劣 化や住戸規模の狭小さによる場合が多く、それらの動機は建替え以 外での対応が難しいからである(事例 A, F, H, K, L，O)。第三に、 管理組合活動が活発なことによる。居住者間の交流が盛んで、建替 えの認識が十分に広まっていたケース (事例 A，E)、日常から管理 に対する関心が高く所有者間での老朽化の認識に大差がないケース

（事例 J, K) 等では比較的容易に建替えが選択されているい。

\section{2 費用負担の困難な者の存在}

合意形成を図る上での最大の㿽路は建替え費用の負担である。自 己負担の有無や負担額の多塞により合意形成の難しさが異なる。ま た、上述の建替えの是非はこの費用負担の問題と密接な関係がある。

\section{（1）等価交換による無償還元床面積が従前住戸を上回る場合}

余剩容積率にかなりの余裕がある場合や立地条件がよい場合、交 換条件が良く従前を上回る無償還元床面積が確保できる（事例 B， $D, E, F, G, H, J, M, O, P$ (10事例 : 表一2)。

これらの事例では、等価交換により従前住戸を上回る50〜 $70 \mathrm{~m}^{2}$ 程 度の無償還元床面積が確保されている。60 $\mathrm{m}^{2}$ 程度以上あれば自己負 担なしにある程度の居住水準の向上が期待されるため、建替えに対 する費用負担面での反対意見は生じていない(事例 $E, F, G, H, J$ ， $\mathrm{M}, \mathrm{O}, \mathrm{P}$ の 8 事例)。

一方、無償還元面積が従前住戸を上回る場合でも、 $50 \mathrm{~m}^{2}$ 程度の評 価しかない場合、建替え前と専有面積がほとんど変わらないため合 意形成に手間がかかることもある（事例 $\mathrm{B}, \mathrm{D}$ )。

\section{（2）等価交換による無償還元床面積が従前住戸に満たない場合}

一方、交換条件があまり良くないため無償還元床面積が狭く、建 替え費用の一部を自己負担せざるを得ないケース（事例 C, K, L ， Nの 4 事例 : 表一2）では反対者が現れる場合もある ${ }^{161 。}$

4 事例とも全戸で追加負担が生じているが、無償還元床面積が従 前住戸に満たないケースでは特に問題となっている（事例 $\mathrm{K}$ )。従 前面積 $45 \mathrm{~m}^{2} 、 55 \mathrm{~m}^{2}$ に対し無償還元床面積は $30.0 \mathrm{~m}^{2} 、 36.6 \mathrm{~m}^{2}$ しかなく、 一番狭い住戸でも最低900万円、700万円の負担が必要であった。

費用負担の難しい者への対応としては、追加負担が少なくてすむ 下階の小規模住戸を用意するのが一般的である。また、ディベロッ パーが資金調達の支援や仮住居の確保等を行いつつ、ねばり強く説 得を行い合意形成を図っている。それでも負担が難しい反対者には、 安い中古マンションや公営住宅の斡旋・紹介を行い反対者を転出さ せる等の対応を行っている（事例 $\mathrm{K}$ ）。

\section{（3）保留床を生み出せない場合}

合意形成を図る上で最も媣刻なケースは建替え費用を全額自己負 担しなければならない場合である（事例 A，Iの 2 事例：表一2）。

保留床を生み出せないケースでは、所有者間の合意形成に難航し

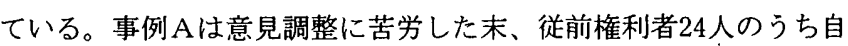
己負担に耐えられる高資力者を除く15名が転出する方針でどうにか 合意に達した。非参加者も基本的には建替えの必要性を認識してい たからである。参加者は戸当たり約2,000万円の自己負担をするこ とになった ${ }^{17}$ 。事例 I は賃貸マンションの払い下げに伴う建替え 事例であるが、116世帯中113世帯の単純売却者が発生した。

このように、従来の建替え実現事例は、費用負担の難しい者を単 純売却というかたちで転出させ、全員合意の下で残りの希望者のみ で建替えを実現しているのである。しかし、このためには買い取り 価格をある程度高く設定し、その販売が見込めるだけの立地条件・ 市場性のほか、経済条件に恵まれていることが必要である ${ }^{18)}$

\section{3 高齢者の存在}

一般に高齢世帯では空間の質的、量的改善に対するインセンティ ブが働きにくいため、手間や費用のかかる建替えには消極的になり がちであると言われる ${ }^{19)}$ 。

調査事例では、無償還元床面積が従前を大きく上回る場合には費 用負担面での反対は生じていない。しかし、従前とほとんど変わら ない場合や従前を下回り、費用の追加負担が生じる場合には何らか の対応が必要となる。特に、高齢世帯の場合、新規ローンを組むこ 
とは不可能であり、費用負担の困難な場合が問題となる。

一般には、ブィベロッパーが追加負担の少ないあるいは必要のな い小規模住戸を設け根気よく説得しているが（事例 B，K，L）、子 供世帯が追加費用分を負担しているケースもある（事例 C, D)。し かし、どうしても費用負担できない場合には安価な中古物件や公共 䝿貸住宅等を紹介・斡旋している(事例 $\mathrm{A}, \mathrm{K}$ )。

このようにして実現事例では高齢者の合意が得られているが、保 留床が生み出せず全額費用負担が必要な場合には、高齡者の合意を 得ることはさらに困難になると考えられる。

一方、自己負担の必要がなくても高齢者が反対するケースもある (事例 B，D，O，Pの 4 事例)。建替え期間中の仮住居への移転によ る生活環境の変化を嫌ったケースであり、子供に説得を依頼したり、 ディベロッパーが仮住居を確保してどうにか合意を得ている。

\section{4 不在所有者の存在}

不在所有者は自己居住所有者に比べて建替えの必要性の認識が希

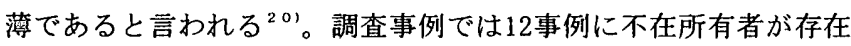
している (事例 A, D, E, G, H, J, K, L, M, N, O, P : 表-3)。

自己負担なしにある程度の無償還元床面積が確保される場合や建 替え後の資産価値の上昇が見込まれる場合には大きな反対は特に生 じていない。しかし一方、費用負担が生じる場合には反対者が現れ ている（事例 A, D, K, Nの 4 事例）。ねばり強く説得するほかない が、やはり今後、費用負担が生じる場合には不在所有者の合意を得 ることも難しくなることが示唆される。

また、不在所有者がいる場合、その所在を突き止めるのに時間を 费やし合意形成が捗らず、その間に賛成者の気持ちが変化してしま う等の問題も指摘されている (事例 A, G, J, L, Oの 5 事例)。

\section{5 法人所有着と隺利洛数}

法人所有者も 12 事例に存在している(事例 C, D, E, F, G, H, J , $\mathrm{K}, \mathrm{L}, \mathrm{M}, \mathrm{N}, \mathrm{O}$ : 表-3)。そのうちの 7 事例は、個人所有戸数よ りも法人所有戸数の方が多い（事例 C, G, H, J, K, L, N)。

一般に、合意形成を図るべき権利者数が多いほど合意形成は難し くなる。ディベロッパーが事業成功の要因の一つに権利者数の少な さを挙げている事例は、すべて権利者数が50人未満である。しかし、 法人所有戸数が多い場合には、合意形成を図るべき権利者数が絞ら れるという利点がある。事例 $\mathrm{G}, \mathrm{H}, \mathrm{J}, \mathrm{K}, \mathrm{L}$ では、住戸数が多いに もかかわらず、法人所有戸数の占める割合が多く、また 1 社が数十 戸単位で住戸を所有しいる(表一 3 参照)。このため、これらの事 例の事業者ヒアリングでは、法人所有戸数が多いほど合意形成は図 りやすくなるという指摘が多かった。また、法人は建替えの検討に あたって 1 社のみが突出することを避けるため、個人所有者の意向 に従う傾向が強い。建替えに積極的でなかったため、全体の合意形 成が進む状況下で転出したケースもある（事例 L)。

このような理由により、調査事例では法人所有者の存在は合意形 成を図る上での大きな障害となっておらず、また、仮住居の確保に おいても他の社宅が利用できるというメリットが指摘されている。

一方、法人所有者が存在することのデメリットとして、建替えに 関する企業の意思決定に時間を要する（事例K）、意志決定者（部 署や本社か支社の別等）が案件によって異なる（事例 $G ） 、$ 契約書 の文面が法人によって異なる要求を出される（事例 F）等の手続き 上の煩雑さが指摘されている。

\section{6 沕的特径}

調査事例では複数棟の団地建替えのケースが12例(事例 B, D, E， $G, H, I, J, K, L, N, O, P$ : 表-2) と多く存在している。

大規模団地の場合、仮住居の確保や事業費の一部を賄うための売 却床の供給等の点から一括建替えが困難な場合が多い。この場合、 敷地分割を行い個別に事業を実施する方法、事業は団地全体で行う が実施は数䡆毎に行い、実施期間による経済的不公平をなくすため 総事業費を最終的に精算する方法の二つが考えられるが、多くの問 題点があり具体的な事業手法は確立していないと言 ${ }^{21}$ 。

実現事例は全て住戸数や橧数からみて必ずしも大規模団地とは言 えない複数楎の団地建替えのケースである。一括建替えが可能であ $\eta^{221}$ 、敨地も全体共有で複雑な権利調整を必要としなかっため問 題は生じていない。一方、建替え検討が中断した 2 事例は、大規模 団地のケースであり（表ー2）、団地建替えの問題点を示している。 事例Qは大規模団地建替えの実現可能性への熄念が居住者の根底に あり、各楎ともに意見調整がつかなかった。事例 Rは大規模団地に 伴う保留床処分の難しさから事業検討を中断することになった。

なお、実現事例には存在しなかったが、非住宅用途との用途複合 型マンション（いわゆる「下駄履きマンション」）では、仮店舗や 仮事務所の確保の困難さや「営業権」の問題等により、非住居部分 の所有者の合意形成が特に困難であると言われている ${ }^{23)}$

\section{7 従前権利の評価と新住戸の位置選定}

従前権利の評価については、各ディベロッパー独自のシステムに 基づいて個別に評価額が設定されるのが一般的である（事例 $\mathrm{A}, \mathrm{G}$ ， $\mathrm{H}, \mathrm{K}, \mathrm{L}, \mathrm{O}, \mathrm{P}$ の 7 事例)。しかし、調査事例では従前の専有面積、 開口方位がすべて同じ板状住䡆のケースが多く、このような場合は 煩雑さを避けるために、従前評価を全戸均一にしている（事例 B， C, D, E, F, I, J, M, Nの 9 事例)。

一方、新住戸の位置選定にあたっては、まず各人の希望を聞き、 それを公表した上で再度全員から希望を䦎くなど、各所有者の希望 調整を丹念に行い、重複した場合は最終的に抽選 ${ }^{24}$ によって決め ている例がほとんどである（事例 A, C, D, E, G, H, J , K, L, M, $\mathrm{N}, \mathrm{O}, \mathrm{P}$ の13事例)。しかし中には、意見対立が生じないように従 前位置による配分方法をとっているケースもある（事例 B, F)。

また、自己居住者と不在所有者・法人所有者が競合した際には自 己居住者優先のルールを設けているケースもある（事例 C, E)。方 位や階によって評価が異なり、交換差金がつかない住戸を手にする

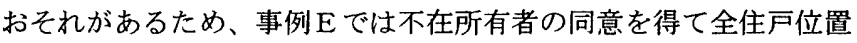
が決定するまでに 2 年を費やしている。

一方、ディベロッパーは、いわば保留床買い取りの受け皿であり、 事業採算性を考慮すれば権利者と同等の立場で住戸選定に参画した いと考える。しかし実際には、合意形成を内滑に図るために再入居 者を優先させる結果、人気のない住戸を引き受けざるを得ないこと が多く、その処分に苦心している例がある（事例C）。極端な場合、 保留床をすべて処分することが難しくなり、事業途中でディベロッ パーが撤退してしまったケースもある（事例 R)。

\section{8 斯完希望者への封応}

事例 F, G,J J 除く実に13事例に、建替えには賛成したものの事 業には参加しない単純売却者 ${ }^{25}$ が発生している（表一2）。特に、 等価交換でない建替えのケースでは、建替え参加者よりも転売者の 
方が多くなっている（事例A，I）。

単純売却者の中には、建替えを機に子供と同居するというケース や他にも住宅を所有しているケースもあり、原則としてディベロッ パーは代替住居の斡旋等の対応は行っていない。しかし、行く当て のない高齢者等には評価額以内で購入できる中古マンションを斡旋 しているケース等もある(事例 $\mathrm{A}, \mathrm{D}, \mathrm{I}, \mathrm{K}, \mathrm{N}, \mathrm{P}$ )。

一方、経済事情や立地条件等により保留床の処分が見込めない場 合、ディベロッパーにとって単純売却者の床を買い取る「うまみ」 は少ない。このため、ディベロッパーが従前の権利を買い取ること はせず、転売希望者には建替え後の新住戸を各自で売却するように 説明しているケースもある(事例 C, E)。

\section{9 仮住居の確保}

マンション建替えにおいては、戸建て住宅の建替えに比べて長期 間にわたって大量の仮住宅が必要となる。各事例とも仮住居は各所 有者個人で確保することを原則としている。一般に住戸数が多くな るほど仮住居の確保は困難となるが、住戸数が100戸を越えるよう な場合でも法人所有や賃借人が多く、自己居住者が少なかったため に、全く問題とならなかったケースもある（事例 $\mathrm{G}, \mathrm{K}, \mathrm{L}$ )。

しかし、高龄者の場合は別である。通院問題等により限定された エリア内で仮住居を確保することが必要な場合が多く、ディベロッ パーが系列会社や地元不動㕍業者に依頼して奔走したケースや確保 するまでに長時間を要したケースは多い（事例 B, C, D, H, L, N, Pの 7 事例)。また、前述したように、高㱓者が仮住居への移転に 拒否反応を示したケースもある（事例 B , D)。

一方、仮住居への移転に伴う費用負担も大きな問題となる ${ }^{26)}$ 。 仮住居費用の一部を事業費の中から捻出したり（事例 B ）、従前居 住者のみに家貨の一部を負担する（事例 $\mathrm{K}$ )、新住戸の引き渡し時 に支払う予定の交換差金を前渡しする（事例 $\mathrm{H}$ ）等、ディベロッパ 一が費用面で対応している例もある。また、仮住居への移転を嫌い 反対する高齢者の合意取り付けのために、仮住居を確保しその費用 を肩代わりした特殊ケースもある（事例 B)。

\section{5. 事業実施段階での問題点と事例にみる対応}

以上の結果、区分所有者全員の合意形成が図られると、建替え事 業に着手することになる。

これまでの建替え事例はすべて全員合意による任意建替えである ため建替え決議を必要としない2》。しかし、事業計画中に生じる おそれのある反対者への対抗のために、全員合意が得られた後に形 式的に建替え決議を行っているケースもある（事例 A, G, L)。そ の後の事業全体のスピードアップが図られたり、地権者の意識上の 大きな転機になるというメリットを指摘する声がある。

ところで、今般の阪神・淡路大震災による被災マンション再建に おいて以様々な事業方式がとられたが、その主なものに「自主再建 方式」「建設型事業代行方式」、「購入型事業代行方式」がある ${ }^{28)}$ 。

調査事例においては、すべてが購入型事業代行方式（全部銥渡方 式及び部分譲渡方式）である。参加者全員がディベロッパーに区分 所有権を一旦諼渡し、新マンション建築後にディベロッパーから再 度分譲を受ける方式であるが、このような手法が主流を占めるのは、 後述するように、建替え団体は建替え事業の主体として法的に非常 に脆弱であるからである ${ }^{29}$ 。
購入型事業代行方式の場合、区分所有者全員の合意が図られた段 階で、建替え業者であるディベロッパーとの間に基本協定 ${ }^{301}$ が締 結される。その後、開発許可や建築確認、国土法等の許認可手続き を経て、権利者全員との売買契約 ${ }^{31}$ の締結に至る。

基本協定を締結した頃から、抵当権者や借家人、近隣住民等の区 分所有者以外の第三者の合意を取り付けることになる ${ }^{32 !}$ 。

\section{1 抵当権の扱い}

抵当権をつけたまま建物を解体することは抵当権の侵害にあたる ため、解体時までに抵当権を抹消しなければならない33!。事例 $\mathrm{A}$ ， $\mathrm{F}, \mathrm{O}$ を除く 13 事例で抵当権が設定されている住戸が存在した ${ }^{34)}$ 。

残債が従前権利の評価額以内であれば、売買契約締結と同時に抵 当権が抹消されることになる。全部譲渡方式を採用する場合は敷地 の譲渡代金で抹消が可能となる世帯もある。しかし、評価額を超え る残債がある世帯については何らかの措置を講ずる必要がある。一 般には、ディベロッパーが金融機関に対して事業の説明を行い、調 整を図って一時抹消の合意を取り付けている（事例 $E, G, J, N$,

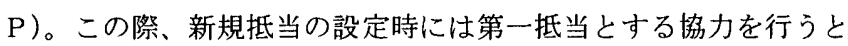
いう旨の文書をディベロッパーが提示したケースもある (事例 J )。

一方、部分譲渡方式の場合、敷地譲渡代金で抹消することは難し く、ディベロッパーに売却しない（従前権利者の持ち分となる）土 地のみにまず抵当権を付け替え、新建物完成後に建物にも設定する という方法で従前ローンを継続利用したケースがある（事例 H）。

また、事業用の根抵当権が設定されている事例も多い（事例 D, G, H, J , Lの 5 事例)。大半は金融機関と交涉して一時抹消の合意 を得ているが、ディベロッパーが最高限度額で買い取って抹消した ケースもある(事例D)。

事業者へのヒアリングによると、抵当権の抹消については一般に バブル崩壊後は金融機関の協力が得られにくくなっていると言う。 一時抹消が難しく、かつ所有者自らで返済できない場合、ディべロ ッパーが所有者の債務を代わりに弁済して抹消するほかないが（事 例 B，C，D）、抵当権者が多数の場合、ディベロッパーの負担が重 くなるという問題がある ${ }^{35 。}$

\section{2 貨貸住戸における借家人への対応}

借家人に対しては賃借契約の合意解約を行う必要がある。事例 $\mathrm{B}$, C，Fを除く13事例に貸貸に出ている住戸が存在する（表一 3 ）。

各事例とも賃借人に対する立ち退き要求及び交涉は、「大家」で ある所有者自らが行うことを原則としている。建替え後の再入居を 保証する場合も多い。しかし、建替えに伴う立ち退き要求は、借地

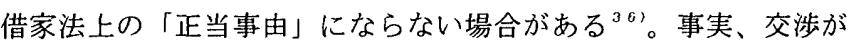
難航し、弁護士をたてて最終的に大家の自己負担で立ち退き料を支 払って解決したケースは多い（事例 $\mathrm{E}, \mathrm{G}, \mathrm{J}, \mathrm{K}, \mathrm{N}, \mathrm{O}$ の 6 事例)。

このように、建替えに伴う借家人の立ち退きをめぐってトラブル になった場合、大家の金銭的負担によって解決しているのが実状で ある。このため、ディベロッパーは大家に対して、建替え検討中に 契約更新時期を迎えた場合、新規更新を行わずできる限り空家を增 やす方針を呼びかけている。しかし、この場合も建替え予定を理由 とする更新拒絶は正当事由と判断され難い等の問題は残っている。

なお、借家人の移転先については、無職その他の理由で新たに借 家を見つけることが困難であるため、ディべロッパーが斡旋等を積 極的に行ったケースはあるが（事例 $\mathrm{H}, \mathrm{J}, \mathrm{K}$ )、基本的には大家、 
ディベロッパーともに特段の対応は行っていない。

\section{3 近绦住民の対応}

近隣住民からの苦情の原因としては、日照障害が最も多く、ほと んどの事例で問題となっている(事例 A, C, D, E, F, G, H, J, K, $L, M, N, P$ (13事例)。そのほか、風害・通風障害 (事例 $D, E, F) 、$ 工事騒音（事例 $\mathrm{A}, \mathrm{G}$ ）に対する苦情が寄せられたケースがある。 対応策としては、まず、地道な折衙を繰り返し行うことであり、 このため各ディベロッパーは近隣担当部署を設けている。日影や狭 い道を工事車両が通行することによる騒音への苦情に対し、60回以 上も折衝を重ねて理解を得たケース（事例 $\mathrm{A}$ )、近隣調整のために 着工が予定よりも 1 年遅れになったケース (事例C) 等がある ${ }^{37) 。 ~}$ 話し合いや計画の微修正で解決しない場合、最終的には、各ディ ベロッパーが設定する基準以下の住戸については、補償金を支払い 解決しているケースが多い(事例D, F, G, H, J , K, Pの 7 事例)。 近隣対策も最終的には金銭的に解決しているのが実状と言える。

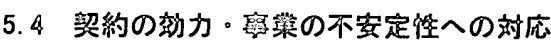

売買契約が締結され、区分所有者以外の第三者の合意も得られる と、管理組合を解散し、建物の解体、着工に入る。この事業実施段 階に至っても契約の効力や事業の不安定性に係わる問題がある。

建替えは比較的長期にわたる事業であるため、その間の経済情勢 の变動の影響を受けや寸い。計画作成の段階で事業採算のとれる見 込みがなくなり、ディベロッパーが撤退し事業が途中で中断してし まったケースがある（事例R）。また、購入型事業代行方式を採用 する場合、従前の土地持ち分を一旦ディベロッパーに譲渡すること から、事業実施中にディベロッパーが何らかの事情で倒産してしま い土地が差し押さえられたり、取り壊し建物を再建しない場合や影 地を第三者に売却してしまうような場合も十分に想定できる ${ }^{381}$ 。

このような問題があるにもかかわらず、従前権利者の権利保全が 図られているケースは少なく、一般に従前権利者にとってリスクを 伴うかたちでの事業進行が多い39)。事例Kは、調查事例の中で唯 一、売買契約後から再入居までの間の従前権利保全が図られたケー スである。法人の強い要求を受けて、ディベロッパーが従前権利評 価額分を金融機関に預け入れそれに質権を設定して対忘している。

一方、ディベロッパーの立場からみても問題は大きい。建替え参 加者とディベロッパーの間で結ばれる基本協定や売䁚契約は通常、 参加者全員がディベロッパーと契約を締結することを停止条件とし て効力を生じることになっている。このため、参加者の一人に何ら かの暇注があり契約が無効となった場合、その他の参加者全員の基 本協定や売買契約の効力も無効となってしまうおそれがある。また、 決議後の事業の進捗途中で参加者が破産し第三者へ所有権を転売し てしまうおそれがある。新権利取得者が建替えに反对である場合、 計画を一からやり直す必要性もある。全部譲渡方式の場合、敨地所 有権を一旦全て事業者に譲渡した後ではこのような事業リスクはか なり解消されるが、実際には税制上有利な ${ }^{40}$ 部分銥渡方式が採用 される場合もある（調查事例では部分僙渡方式が 7 例を占める：表 $-2)$ 。この場合は事業参加する従前権利者が等価交換後の土地持 ち分を保有したまま事業を進めるため事業りスクは依然として残 る。すなわち、建替え団体に法人格が付与されない現状では、売買 契約は全ての権利者と個々に交わす必要があり、一人でも欠ければ 亦業が成立しないという不安定性が常に付きまとうのである。
このような事業の不安定さを払拭するために、基本協定や壳買契 約には、建替え参加者は事業の遂行に協力しなければならないとい う旨の規定が盛り込まれるのが一般的であり ${ }^{41}$ 、ディベロッパー によっては、規約に転売住戸の新規の取得者に対しても継続的な事 業参画を明記しているケースもある（事例 L)。さらに、基本協定 締結後の第三者への転売による事業の不履行が生じた場合には、損 害賠償を請求することを明言しているケースがある（事例 J)。し かし一方で、損害賠償の請求を売買契約書に明記しても、いわば「生 活権」とでも言うべきより上位の概念の下では、それがほとんど効 力を及ぼさないと指摘するディベロッパーは多い。事実、先に述べ た事例 J, L以外の 14 事例は、いずれも「基本協定」と「建替え決 議書」の締結以外には特別な対応を行っていない。

実際、問題がなかったわけではない。実現事例でも決議後に転売 が生じたケースが 2 例ある。そのうちの一例は建替え実施を承知の 知人に売却したり、ディベロッパーが買い取ったケースであるが(事 例 J 、、もう一例では事業採算上、ディベロッパーは破産した参加 者の権利買い取りを跜躇したが、組合理事長が私費で買い取り、ど うにか事業の不成立を回避している(事例 $\mathrm{H}$ )。

以上のように、分譲マンション建替えにおいては、困難な合意形 成が図られた後の事業実施段階においても、第三者の合意取り付け 費用の大きさ、契約の不安定さや事業の不確実性等の従前権利者、 事業者双方にとってのリスクが存在している。これは建替えの事業

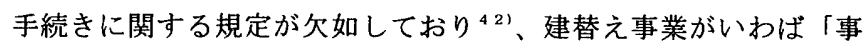
業法」に立脚して実施されない点に起因していると言える。

\section{6. 紷譣}

\section{1 従来の建替え察現の㱠因}

調査事例を通して、建替え実現の要因を整理すると大きくは以下 の 6 点が指摘できる。

(1)容積率の余裕

これまでの建替え実現の最大の要因は、容積率に余裕があり、等 価交換による建替えが可能であったことである。特に従前の容積率 充足比が小さく、等価交換後の無償還元床面積が $50 \sim 60 \mathrm{~m}^{2}$ 程度以上 あれば費用負担面での合意形成は比較的容易であった。

(2)立地条件・市場性

立地条件は従前資産の評価額に影響を及ぼす。従前建物の容積率 に余裕があったとしても、保留床が大きくなるほどその販売の見込 みがなければ事業は成立しない。それを可能とする立地条件・市場 性が不可欠であった。

\section{(3)自己負担が困難な所有者への対応}

容積率の余裕と立地条件・市場性により、費用負担のない等価交 換建替えが可能であったこと及び自己負担が必要な場合に凟金負担 の難しい所有者に対してディベロッパーが資金調達を支援したり、 権利を買い取り転出させた上で全員合意の下で希望者のみで事業を 進めることができたことが事業成功の大きな要因である。

しかし、そのような費用負担面での有利さだけで建替えが実現す るわけではなく、その他、以下のような要因が不可欠であった。

(4)少ない権利者

権利者が少ないほど意思統一は図りやすく、一般に戸数規模が50 戸未満では合意形成は比較的容易になっている。ただ、戸数規模が 
多くても多くの住戸を所有している法人が数社ある場合には権利者 数が絞られるというメリットがある。合意形成を図るべき権利者数 が少ないことを事業成功の最大の要因に挙げている事業者も多い。 また、権利者数が少ないことは仮住居を確保する上でも有利である。 (5)ディベロッパーによる適切なサポート

反対者や高齢者に対する説得や諸条件の提示、所有者の意見をう まく調整しながらの事業計画のとりまとめ、抵当権者や借家人、近 隣等の第三者への対応等、ディベロッパーの適切かつねばり強いサ ポートにより、事業を円滑に進渉させることができた。また、事業 実施段階においてディベロッパーの信用力の高さや仮住居の確保に おける系列会社等との連携も事業を円滑に進める要因となった。

(6)推進組織のリーダーシップ

実現事例には、所有者と事業者とのつなぎ役として重要な役割を 果たした推進組織が存在した。このリーダーシップにより、所有者 の多様な意見・希望のとりまとめが可能となるとともに、事業途中 で生じた参加者の離脱等の大問題にも迅速かつ適切に対応すること ができた。また、強力なリーダーシップのもと権利者全員が建替え 事業をよく理解し、事業実施段階においても第三者への転売等がほ とんど発生せず協力的であったことも事業成功に不可欠であった。

\section{2 今後のマンション建替え施策の整備・開発の方向性}

今後の建替えにおいては等価交換は難しく ${ }^{43)}$ 自己負担が必要と なる。しかし、今後の社会経済情勢下では費用負担力のない者を転 出させる方法もあまり期待できないと思われ44，費用負担力のな い権利者の合意形成を図る条件づくりが必要である。中断事例にみ るように大規模団地の建替え手法が確立していない点、建替え事業 が法的担保を得られず非常に不安定である点も重大な問題である。

円滑な建替え実現のために解決すべき課題は多いが ${ }^{45} 、$ 特に早 急に整備すべき施策の主な方向性として以下の点が指摘できる。

(1)円滑な建替え方針決定のための条件整備

初動期において、建替え方針が円滑に決定されるための条件整備 （ルールづくり、資金づくり等）が必要である。建替えを大規模修 繥計画の中に位置づけた、マンションの将来運営に係わるマスター プランの作成及び建替え資金づくりの制度化 ${ }^{46)}$ 等が考えられる。

(2)費用負担困難者の合意形成手法の開発

建替えへの全員合意の条件づくりが必要である。費用負担が困難 な者の権利を建替え後は戸別に定期借家（利用）権に変換し、建替 え費用の負担なしに（他の参加者から徽収する修䌜積立一時金を充 当し）継続居住を可能とする事業手法の開発 ${ }^{47}$ 等が考えられる。

(3)団地建替え手法の開発及び立法化

団地の合意形成手法・建替え手法を開発し、立法化する必要があ

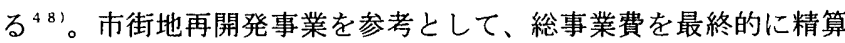
することができる組合を構成し、かつ広い地域を長期にわたって整 備していく要網事業制度の性格を併せ持つ手法、賛成者と非賛成者 の意見調整のために団地内の住戸交換を行い部分建替えを円滑に実 施する仕組み等を考える必要があると思われる。

\section{(4)事業安定化のための建替え事業制度の創設}

区分所有法とは別 ( $^{49}$ 合意形成後の事業手続きを制度的に定め、 確実かつ安定的な事業実施を保証する必要がある。合意形成が図ら れた事業に対し、「公益性」の度合いに応じて、抵当権、借家権等 の（行政処分による）一括権利変換、都道府県知事（市町村長）に
よる事業認可による建替え団体への法人格の付与、事業者の離脱に 対する代行措置、等が規定されるべきである。

\section{謝辞}

本研究は、建設省総合技術開発ブロジェクト「投資効率向上・長斯而拥都市型集合住

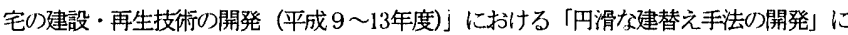
関する初年度の研究成果の一部を筆者の責任においてとりまとめたものである: 調查に こ協力をいたたいた関係各位にこの場を借りて謝意を表する次第である。

注

1）被災マンション再生において露呈した問題点については文献1、2に詳しい

2) 文献 3

3) 文献 $4 、 5$

4) 文献 $6 、 7$

5) 文献 8

6) 実務の視点から事業実施段階での問題点について指摘したものに文献 9、10がある,

7）文献11によると、被災した分譲マンション544棟のうち540棟で合意形成が図られ、 うち104棟が建替え済みあるいは事業中である。

8）容積率充足比が「1」を越えているものは、総合設計制度等の活用事例である。

9）従前の容積率充足比や准戸数等がとくに等価交換条件を左右寸る。調查対象事例は 全体の分布の中からくまなく抽出されており、サンプリングとして適切であると言 えよう（図ー2）。また、全戸費用負担の生じた建替え事例は原則費用負担の必要 のないものに比へて合意形成が難しく今後の建替え施策を考える上で特に示唆に富 むと思われるため、これらの事例については可能な限り調查対象に含めている。

10）調查対象事例山建築年からみても昭和30年代前半のものが多く、全体の傾向と一致 していると言えよう。なお、表には示していないが、当初の分讓主体はやはり公団 ・公社、建替え業者は民間が中心である。

11）特定の専門家の協力を受ける場合、管理組合の委任・承認を受けていないと建替え 反対の意向を持つ区分所有者等から「痹着」であるという非難を浴びることがあり、 せっかくの建替え機運が後退してしまうことがある。そのため、できる限り早く管 理組合の承認または委任を受け、区分所有喤から認知された組䋨にする必要がある。

12）建替えの意向等に関するアンケート調查の結果、建替え希望が少なくとも概加 $3 / 4$ 以上から4/5程度に達していると、管理組合総会にて承認された組織を設置して、 全員の合意形成を図っていくことになる。一方、建替え希望者が $3 / 4$ にも満たな い場合には、その後の専門家の参画が正当化されえず、仮に建替え計画を立案して も成立の見込不恃少ない。こ建替え準備期の活動内容については文献8に詳しい。

13）調查事例によると、建替えを検剧するに至った重機は、(1)建物の老朽化（全18事例)、 (2設䜤の老朽化・1日式化（10事例)、(3)狭小な住戸 (8事例)、(4修䋨維持費の增大 (5事例)、(5)他の建替え事例からの影響（5事例)、等である。

14）被災マンション再建における係争中の事例もすべてが、建替え（再建）加改修（復 旧）かの判断、特に区分所有法で規定している「費用の過分性」をめぐるものであ る(文献11)。また、被災マンションを除く一般建替えにおける同様の挀訟事例と して、新千里桜ヶ丘住宅無效雄認事件がある。二れは地分所有法62条に基づく法定 建替え決議の第一号であるが、「費用の過分性」が满たされていないことや賛成派 が決議に際して態度の消極的な者をとりあえず賛成だけしてくれるよう誘尊したと して、反対派が無効確㪊訴訟を起こしている(1996年12月提訴)。

15) 被災マンション再生においても、(1)自主管理等を通じて居住者の維持管理への関心 が高い、(2)管理組合活動が活発である、(3)良好なコミュニティが酩成されている、 等の場合は建替え・大規模改修の判断が比㜞的容易に行われた。文献 1 に詳しい。

16）事例C、Lでは反対者は当初加基本的に存在しなかったが、事例 $\mathrm{K}, \mathrm{N}$ では権利 者数にして2〜3割め態度保留者・反対者が当初存在していた。

17）表一2では、容積率充足比は建替え後も余裕があるように見えるが、実際は（前面 道路が $4 \mathrm{~m}$ と㹨いため) 指定容積率200\%のところせいぜい $160 \%$ しか使用できず、 保留床が生み出せないことが判明した。容積率 $160 \%$ で計算すると、従前の容積率 充足比は「0.63」、建替え後は「0.88」になる（図一2ではこの值を用いている）。

18）ディベロッパーへのヒアリンク調查によると、買い取り価格をある程度高く設定し 転出させることができたのは経済条件が良好な時期に検討を行ったからであり、バ ブル崩罗後は保留床の処分が困難になりつつあるという。今後、転出者の床を買い 取ることは事業者にとって負担は大きく、この手法が常に採用できるとは言えない:

19）文献12に詳しい。桜上水団地では60歳以上が 7 割を占め、団地住民の高龄化が建替 えを阻む要因となっていること、熒谷アパートでは従前床面積が小さい(10坪程度) が高龄所有者の増休ニーズが(資金不足等で)希薄であること等が指摘されている

20）文献12。同潤会青山アパートの例が挙げられている。

21）文献9、10 前者の方法で忖団地内の位置の違いよる地価の差、分割位置、実施 期間による経済的不公平を処理して合意寸ることが難しく、後者では、長期にわた る精算の難しさとそい管理者の位置つけが不明確であり実現性にそしいと言う 
22）複数棟の場合、团地全体の管理に関しては一棟の建物に関する規定が淮用されるが、 建替えの場合には淮用されず一棟毎に判断する必要がある，一部住棟のみを建替え る場合には、敭地利用の変更を伴う場合の管理組合の位置づけ、一部住棟が建替わ つた場合の放地管理等の考え方に問題がある，文献 9 , 10に詳しい

23）文献12. 同潤会青山アハーートの例を挙げており、事務所・店舗として利用されてい る権利者の合意形成がが難しく実現の道筋が見えないとしている 事例Qも下階に 店舗がある棈では住居所有者との意向の違いが合意失敗の理由の一つである。

24）区分所有法では、建替え決議軎㖽の一部として、「再建建物の区分所有権の营用負

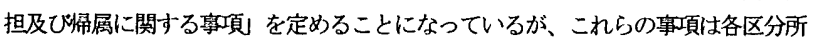
有者の衡平を害しないように定めなければならないとある（62条2 項及び3項， 抽選に外れた場合等、この衡平をめぐって争いになることも十分にあり得る

25）任意建替えでは、費用負担力のない者への最終的な対応策として、このような単純 克却者を聅成者とカウントして全員合意に等いている、しかし、法定建替えの場合、 建替え事業への不参加者であるので反対者とみなし区分所有法63条 1 項の催告を受 けるべきものと判断されるのか磑か等の解釈上の暧昧さがあると言う(文献13)

26）文献14によると、旧マンションから仮住居への移転、仮住居先での敭金・礼金・家 䋕、新マンションへの再移転費用等で約200〜400万円/世帯かかるという。

27）法定建替え決議要件の一つである「老朽化」についてはその概念が暧昧であるが、 立法の経緯から見ると建物の経年変化仁伴う物理的老朽化を想定していると言える (例えば文献15)。このため、注13で示したような、建物の物理的老朽化以外の理 由による建替えは法定建替えでは困難であり全員合意が必要となる：また、物理的 老朽化による建替えの場合であ「费用の過分性」要件により決議の無効が主張され

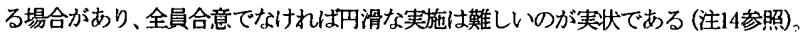

28）例えば文献2がある,

29）建替え団体には法人格ぶ付与されない。また、同様の指摘をしたものに文献 2 及び 文献16がある. 文献16において、丸山は区分所有法は自主再建方式を想定していた が事業的視点を欠いているためにこの方式が採用されにくいことを指摘している。 なお、自主再建方式は费用負担が少なくて扽汃、建替え団体の法的位置ぶけが弱 く権利者数が多くなると手続きが煩雜になるため、被災マンション再建においても 権利者数の少ない小規模マンション以外にはあまり採用されなかった（文献 1)。

30）基本協定は建替え参加者がディベロッパーと買戻予約付きの旧住戸の区分所有権及 ひ放地の共有持ち分の詨渡契約を結ぶことを約し、ディベロッハーは旧建物を取り 壊して新建物に建替えること、参加者は事業の遂行に協力すること等を規定する。

31）壳賢契約は建替え参加者が土地の持ち分と旧住戸の区分所有権をディベロッパーに 讓渡し、ディベロッバーは旧建物を解体し新建物を建てた上、新住戸の区分所有権

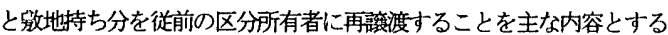

32）ディベロッバーとの間に締結される売買契約茟には、建替え参加者は讓渡土地持ち 分及び旧住戸に抵当権及ひ賃借権などの所有権の行使を阻害する一切の権利が設定 されていないこと、という旨の規定が盛り込まれるのが一般的である。

33）市街地再開発事業では、行政行為による一括権利変換により、從前の抵当権は新し い建物にそのまま移行することになる。後述の借家権の場合も基本的に同様である。

34）建築年の比翰的新しい事例Dでは大半の世帯に抵当権がついていた その他の章例 は昭和 30 年代前半の物件ということもあり抵当のある世带はいずれも梅利者の半数 以下である：しかし、阪神大层災の再建においては、一住戸の抵当権者の意向が全 マンションの再建に多大な影響を及ぽ寸こともあったと言う（文献17）、

35）もちろん民法378条の「てき除」を使ってディベロッバーが抵当権者に対して抵当 権の抹消を請㛏るといら方法はある、しかし、第三者であるディベロッハーが「て き除」を申し出ることは実際上金融機関との間に敵対関係を生じさせることになる ためあまり用いられない。また、「てき除」により抵当権を抹消寸ると当該㬋務者 は以後信用力のない者として扱わ机、事業及ひ生活上に支障をきたすおそれがある。

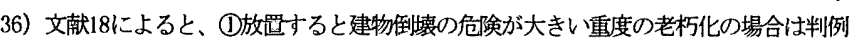
・学锐で徤替えの必要性をもって正当事由が認められるとしているが、(2)老朽化 がす寸んでいるが直ちに倒壊のおそれがあるわけではない中度の老朽では老朽化は 明け渡しの決定的要因とはならず、(3)老朽化が(2)の段階に達していない軽度の老朽 化では老朽化は建替えのための借家明け渡しの正当事由にはならないとしている 任意建替えの場合、法定建て替えとは異なり、建物の社会的陳腐化による建替えも 多く、「老柯化」の判断と正当事由の関保は特に難しいと言えよう

37）とくに総合設計制度等を利用する場合、その手続きを進める上で近隣合意は必須と なり、そのために様々な調整を図る必要が生じる

38）前者の問題については、詐欺による契約取り消し(民法96条) や资務不履行による 解除（民法545条）等の対抗手段を取りうることになる。しかし、詐欺による取り 消しについては詐欺の事実を知らない善意の第三者、佔務不履行による解唋につい ては移転登記を備えた第三者には対抗できないという限界がある、一方、後者の問 題については、売買契約茟にディベロッハーは土地を第三者に淁渡したりしてはな らないこと保証する旨が契約に盛り込まれる場合が一般的である

39）従前権利者サイドから見ると、現状ではい中ばブィベロッハーのネームバリューや
信用力の高さに依存している面が大きい，なお、市街地再開発事業では、事業認可 の際に施行者の経済的基礁その他事業完遂能力に基つく知事の認可制度をとってお り、事業の継続が困難になった際には都道府県知事または市町村長が亭業代行する 規定が措置されている

40）全部䃥渡方式の場合、まず共有持ち分が一旦従前の所有権からすべてディべロッハ 一に売却され新建物建設後に今度はディベロッハーから徙前権利者に権利が移転さ れるこの際、ディベロッハーと従前権利者（地主）に対して、登録免許税と不動 産取得税が二重に椋せられることになる（登記には中間省略登記が可能であるが、 不動産取得税は取引の実態に即して課される)，一方、部分淁渡方式はその手続き が煩雑であるというデメリットもある

41）市街地再開発事業では、組合に対して有する権利義務は承繼した者に移転すること になり、承継人は従前権利者と同様に拘束されることになる。

42）区分所有法には合意形成に至った後の事業実施に関してはなんら規定が去い:この 問題は法定建替え、任意建替えを問わず、すべての建替え事業に関わる問題である

43）今後は昭和40年代前半（第二次ブーム）に大量に建設されたものが建替え期を迎え る. 築 30 年以上の物件の容䖽率充足比は、公団ではほぼ100\%が「1」末満である が、民間では3/4以上が「1」以上の既存不適格であるとの報告もある (文献19)

44）注18参照，一方、既存不適格の場合等は単純売却圱がいなけれは建替えが実現でき ないといら側面もあり、このような法による調整が全員の合意形成において有用 であるとの指摘もある（文献20）。だし、費用負担が難しくとも継綂居住を希望 する者への対応を図り、事業者が参入できる手法を考える必要性は大きいであろう

45) 今後の課題を体系的に整理したものに拙稿・文献1方ある.

46）文献22において、梶浦的费用負担の条件づくりが何よりも必要であるとして、建替 え䅡立金制度を提案している

47）定期借家権の成立が前提である. そうなれば [定期利用権」の実用化が可能となる 定期借家 (利用) 権が終了するとそれを管理組合は売却し、その)凟金で大規模俢穑 を行う。また、一定の家赁を払って住み続けられるタイブも考えられる、ただし、 定期借家の期間の設定、将来の中古価格の下落リスクへの対処等の課題がある

48）団地建替えについては区分所有法にも規定されておらず、事業者は解䣋で夷施して いるというまさに「無法地带」である。具体的な合意形成手法及ひ事業方法を開発 し、その考え方を区分所有法に規定もしくは别法として立法化寸る必要があるう

49）区分所有法々権利の保绫と調整を目的とする法律であるため、同法に章業実施につ いての規定を設けることは国蜼力も知れない。こため、同法とは別に（補完とし

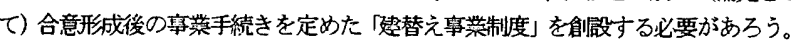

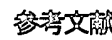

1）「生る11棟のマンションー阪神大霞災・再生への苦䦳の記録、日経アーキテクチュ ア編、1997年1月 2) 我正晴、井口筧司 : 被災マンション復興をめぐる諸問題(上) 一復興の現場からの報告、NB L586号、1996年2月3）前田昭彦、内田雄造 : 分 变マンションのリニューアルをめぐる諸問題一同潤会アパートの建て替えをめぐって、 日本都市計画学会学術研究論文集、第25号、pp.757 762、1990年11月 4 4) 米野史

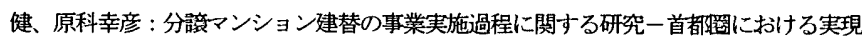
事例を対象として、日本都市計画学会学術研究稐文集、第28号、pp. 157 162、1993年 11 月 5) 高見沢邦郎、與祐一郎、初期に建てられた分变マンションの)実態と建替 之問題の今後の方向性について、日本建勧学会計画系睮文報告集、第A04号、pp.89〜97、 1989年10月 6) 呉祐一郎、高見沢邦郎 : 初期の分变中高層集合住宅の実態と建替え への問題点についてーその 3 . 建替えタイブの設定とタイフ別構成比の推定、日本建築 学会大会学術請演梗概集、pp. 379 380、1990年10月 7) 米野史健 : 分㜔マンショ 乙建替の実現可能性の推定一東京都区部における民間供給物件を対象として一、日本都 市計画学会209、1997年Vol.46/No.4 8) 米野史健 : 分謧マンション建替の合意形 成ブロセスに関する研究一首都圈に抠引る夷現事例を対象として一、日本建築学会計画 系論文集、第505号、pp. 151〜158、1998年3月９）大西誠：老朽マンションの建替 え事業、法律時報、1998年70巻 3 号 10) 大西誠：マンション建替えの実務的䛺題と 新たな施策について、第13回ハウジンク研究報告集、1997年2月 11) 稲本洋之助 : マンションの復興と貄替え制度、法律時報1998年70巻3号 12）村田、高津ほか：分 喰マンションの要うつ(上)、日経アーキテクチュア、1995年6月 5 日号 13）鉡野邦 樹 : マンションの建替えについてー阪神大屋災の経験と区分所有法の問題点、土地総合 研究1998年夏号 14）(財)マンション管理センター : 分钲マンション建替えマニュア ル、1993年3月 15）高柳雄：改正区分所有法の解跘、1983年 16）丸山英気 : 建替えの事業手法一都市学の現場から20一、不動产籃定 34 巻2号 17) 梶浦恒男 : 霞 災と復興をめぐる諸問題ーマンション建替え、建築杂隹誌1996年 1 月号 18) 分謡マン

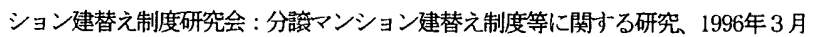

19）(財)トラスト：マンション建替えに関する調查研究(完) 報告㶳(概要)、1990年3月 20）丸山英気 : 建替えの事業手法一都市学の現場から20一、不動産籃定 33 巻9号、1996 年9月 21）拙稿: 分諁マンション建替えの課題と建設省マンション総つロU検討方 針、住宅vol.47、1998年12月 22）㭾浦恒男：日本におけるマンシション建替え問題、 寸末いろ/41号、1997年1月 